\title{
ANTIPYRETIC ACTIVITY OF CENTELLA (CENTELLA ASIATICA (L.) URBAN) HERB IN VACCINE INDUCED MICE
}

\section{NYI MEKAR SAPTARINI ${ }^{*}$, ENDAH KARTIKAWATI²}

${ }^{1}$ Department of Pharmaceutical Analysis and Medicinal Chemistry, Faculty of Pharmacy, Universitas Padjadjaran, West Java, Indonesia 45363, 2Department of Pharmacy, Faculty of Mathematic and Natural Sciences, Al Ghifari University, West Java, Indonesia 40293

Email: nyi.mekar@unpad.ac.id

Received: 30 Sep 2020, Revised and Accepted: 20 Oct 2020

\section{ABSTRACT}

Objective: This study aimed to determine the antipyretic activity of the infusion of centella (Centella asiatica (L.) Urban) herb, based on empirically usage of Indonesian people.

Methods: Antipyretic activity assay was conducted to Swiss-Webster mice, which induced by diphtheria-pertussis-tetanus (DPT) vaccine with paracetamol as positive control.

Results: Centella herb was contained tannins, flavonoids, monoterpenoids, sesquiterpenoids, triterpenoids, steroids, and saponins. The antipyretic activity of centella infusion has a ratio 1:44.6, compare to paracetamol.

Conclusion: Antipyretic activity of centella herbs was predicted due to its secondary metabolites.

Keywords: Centella, Infusion, DPT vaccine, Paracetamol

(C) 2021 The Authors. Published by Innovare Academic Sciences Pvt Ltd. This is an open access article under the CC BYlicense (https://creativecommons.org/licenses/by/4.0/) DOI: https://dx.doi.org/10.22159/ijap.2021.v13s3.16 Journal homepage: https://innovareacademics.in/journals/index.php/ijap

\section{INTRODUCTION}

Centella (Centella asiatica (L.) Urban), known as Indian pennywort or Asiatic pennywort, is a perennial plant and herbaceous in family Apiaceae [1]. The people of Java and Indonesia use this herb as phytomedicines [2] to treat infection, inflammation, poison, fever, laxative, leprosy, virus, wound healing, strengthens the body's tissue structure, and brain tonic [3]. This herb also has adaptogens activity, i.e. reduce stress reactions in the alarm phase and provide a certain degree of safety against long-term stress [4], enhancing memory, and treatment of skin diseases and nervine disorders [2].

Flavonoids, glycosides, tannins, alkaloids, triterpenes, steroids, and saponins are identified in centella extracts [5]. Asiatic acid, asiaticoside, and madecassoside are the major constituents, which responsible for pharmacological activities, beside flavonoids and terpenoids [6]. Indonesian people use centella as an antipyretic, i. e 30-60 g of fresh herbs boiled in $600 \mathrm{ml}$ of water to produce $200 \mathrm{ml}$ of dilute water extract. This extract was consumed until the symptoms is reduced [3]. This study aimed to determine the antipyretic activity of the infusion of centella herb, based on the empirically usage of Indonesian people.

\section{MATERIALS AND METHODS}

\section{Materials}

Centella herb was collected from Manoko, West Java, Indonesia, and identified by Plant Taxonomy Laboratory, Faculty of Mathematics and Natural Sciences, Universitas Padjadjaran, Indonesia.

Swiss mice (18-25 g) was obtained from Center for Biological Sciences, Institute of Technology Bandung, Indonesia. The animals were kept in clean cages and fed with standard pellet diet with ad libitum water for seven days to acclimatize. The procedure of antipyretic activity assay had been approved by the Research Ethical Committee of the Faculty of Medicine, Universitas Padjadjaran, Indonesia.

DPT vaccine was purchased from PT. Biofarma, Indonesia. Paracetamol with pharmaceutical-grade was purchased from China. All chemicals with analytical grade were purchased from Merck, i.e. ferric chloride, hydrochloric acid, sodium hydroxide, sodium acetate, n-hexane, methanol, chloroform, sulfuric acid, glacial acetic acid, ethanol, ether, and Mayer, Dragendorff, and Bouchardat reagent.

\section{Methods}

\section{Samples preparation}

Centella herbs were extracted with distilled water in an infusion apparatus for $15 \mathrm{~min}$ at $90{ }^{\circ} \mathrm{C}$. Phytochemical screening for secondary metabolites in simplicia and infusion was conducted with Tiwari et al. method. This method was conducted with specific reagents to detect alkaloids, flavonoids, polyphenols, tannins, monoterpenoids, terpenoids, steroids, quinones, and saponins [7].

\section{Antipyretic activity assay}

Antipyretic activity was determined by modifying method which described by Saptarini and Deswita [8]. The mice were divided into five groups $(n=5)$. Basal rectal temperatures were measured by introducing a $1.5 \mathrm{~cm}$ digital thermistor thermometer (Model MT101, N and B Medical). Pyrexia was induced by injecting $0.1 \mathrm{ml}$ of DPT vaccine subcutaneously. After $4 \mathrm{~h}$ of DPT vaccine injection, all mice were treated orally with (I) 2\% PGA (Arabic gum suspension); (II) paracetamol $1.3 \mathrm{mg} / 20 \mathrm{~g} \mathrm{BW}$; (III) centella infusion $58.5 \mathrm{mg} / 20$ g BW; (IV) centella infusion $117 \mathrm{mg} / 20 \mathrm{~g} \mathrm{BW}$; and (V) centella infusion $234 \mathrm{mg} / 20 \mathrm{~g} \mathrm{BW}$. The rectal temperatures of the hyperpyrexic mice were measured each $30 \mathrm{~min}$ for $3.5 \mathrm{~h}$ [9].

\section{Statistical analysis}

Data were presented as mean \pm standard deviation. Data were analyzed by one-way ANOVA followed by Newman-Keuls. Values were considered statistically significant at $\alpha<0.05$.

\section{RESULTS AND DISCUSSION}

Empirically, 30-60 g of fresh centella herbs were boiled with water to produce $200 \mathrm{ml}$ of infusion, which was used as an antipyretic folk medicine [3]. In this study, the doses of centella herb were 22.5, 45, and $90 \mathrm{~g}$. The dose was multiplied by the conversion factor for mice, i.e. 0.0026 . So the doses of centella herb for mice were $58.5,117$, and $234 \mathrm{mg} / 20 \mathrm{~g}$ BW. A total of $30 \mathrm{~g}$ of centella herb simplicia was infundated with $100 \mathrm{ml}$ of water produced a $78 \mathrm{ml}$ of liquid infusion, so the concentration was $0.38 \mathrm{~g} / \mathrm{ml}$. Centella infusion was blackishgreen in color with slightly centella fragrant. Based on the calculations, the infusion volume, which given to groups III, IV, and V were $0.154,0.308$, and $0.616 \mathrm{ml}$, respectively. 
The results of phytochemical screening showed that the secondary metabolites of infusion were the same as simplicia, i.e. tannins, flavonoids, monoterpenoids, sesquiterpenoids, triterpenoids, steroids, and saponins. This result showed that secondary metabolites in simplicia were completely extracted in infusion and heating during infundation does not damage the secondary metabolites. The result was in accordance with the literature [5]. Infundation was chosen as the extraction method because adjusted to boiling, which is empirically carried out in the community [3].

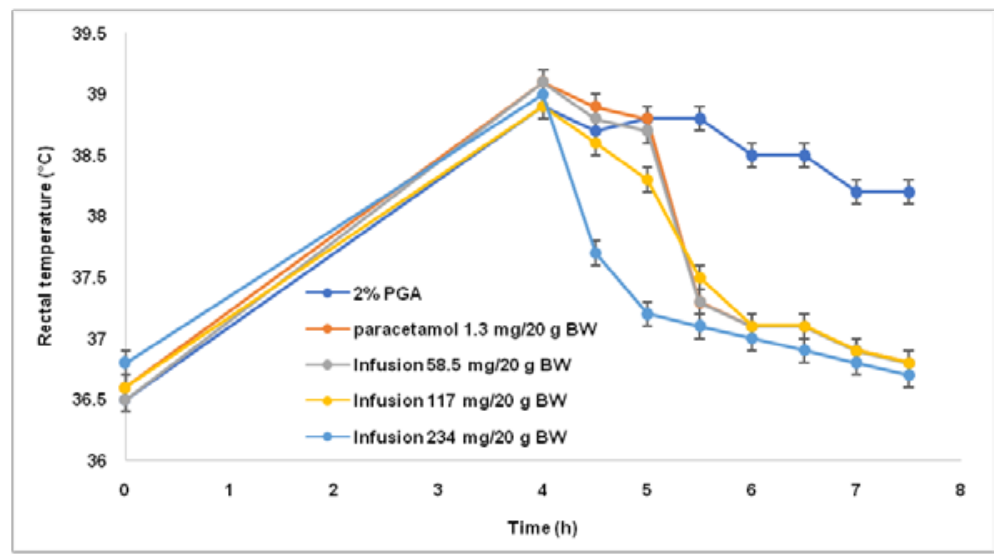

Fig. 1: Antipyretic activity of centella infusion

The DPT vaccine causes fever, even up to $41^{\circ} \mathrm{C}$, due to the whole-cell Bordetella pertussis [10]. The DPT vaccine increased all mice rectal temperature and produced an increasing time-dependent on the mice rectal temperature, from normal $\left(36.6 \pm 0.2{ }^{\circ} \mathrm{C}\right)$ to $38.9 \pm 0.3^{\circ} \mathrm{C}$, after $4 \mathrm{~h}$ of DPT vaccine injection (fig. 1). Paracetamol is potent antipyretic and analgesic, which inhibits cyclooxygenase isoform selectively in the central nervous system to inhibit PGE2 synthesis to achieve its antipyretic activity [11]. Paracetamol as a positive control was reduced the mice rectal temperature, from $39.1 \pm 0.1{ }^{\circ} \mathrm{C}$ after $4 \mathrm{~h}$ of DPT vaccine injection to $36.8 \pm 0.2^{\circ} \mathrm{C}$ after $3.5 \mathrm{~h}$ of drug treatment. There was a decreased temperature of $2.3{ }^{\circ} \mathrm{C}$ due to the paracetamol action (fig. 1).

The dose of $234 \mathrm{mg} / 20 \mathrm{~g}$ BW gave the fastest temperature reduction, i.e. $1 \mathrm{~h}$ after infusion treatment. The dose of $58.8 \mathrm{mg} / 20 \mathrm{~g}$ BW produced the same temperature reduction pattern as paracetamol $1.3 \mathrm{mg} / 20 \mathrm{~g} \mathrm{BW}$. The antipyretic activity of centella infusion has a ratio of 1: 44.6, compare to paracetamol. All centella infusions can lower the rectal temperature back to the basal rectal temperature with a decrease in temperature almost the same as paracetamol after $3.5 \mathrm{~h}$ of infusion, i.e. $2.1-2.3{ }^{\circ} \mathrm{C}$ (fig. 1). Centella infusion activity was dose-independent. It was observed that the increased dose was not proportional to the decreased rectal temperature. Statistical analysis showed no significant difference in all test groups $(\alpha>0.05)$.

There is no single chemical compound is responsible for the medicinal properties of plant-based drugs. The synergic action is caused by the presence of other chemical compounds in the plant. Terpenoids [12, 13], triterpenoids [14], tannins [14, 15], saponins [13], flavonoids, and steroids [12-15] may be responsible for antipyretic activity in plants. The phenolic compounds, such as tannins and flavonoids, are an inhibitor of arachidonic acid peroxidation, which results in the reduction of prostaglandin levels, thus reducing fever and pain [16]. The antipyretic activity of flavonoids may be caused by involving in inhibition of PGE2 synthesis and suppress the tumor necrosis factor- $\alpha$ [17]. Steroids change pyrogen release from leukocytes; the alterations in steroid balance influence normal temperature regulation and contribute to fevers [18]. The antipyretic action of the medicinal plant may be through the inhibition of PGE production, leading to suppression of increased plasma levels [2].

\section{CONCLUSION}

Centella herb infusion was provided an antipyretic activity equivalent to paracetamol. There was no significant difference between three doses of centella infusion.

\section{FUNDING}

Nil

\section{AUTHORS CONTRIBUTIONS}

All the authors contributed equally.

\section{CONFLICT OF INTERESTS}

Declared none

\section{REFERENCES}

1. Shanghai PR. Jiangsu new medical college. Dictionary of Chinese Materia Medica. China: Shanghai Scientific and Technical Publishing House; 1977.

2. Jamil SS, Nizami Q, Salam M. Centella asiatica (Linn.) Urban-a review. Nat Prod Radiance 2007;6:158-70.

3. Dalimartha S. Atlas of Indonesian medicinal plants. Vol. II. Jakarta: Trubus Agriwidya; 2000.

4. Wagner $\mathrm{H}$, Norr $\mathrm{H}$, Winterhoff $\mathrm{H}$. Plant adaptogens. Phytomedicine 1994;1:63-76.

5. Somasundaram T, Maheswari KU, Suneetha JW, Prasad TNVKV, Rajeswari B. Screening for plant secondary metabolites in selected indigenous herbal plants. Imperial J Interdisciplinary Res 2016;2:1103-6.

6. Roy DC, Barman SK, Shaik MM. Current updates on Centella asiatica: Phytochemistry, pharmacology and traditional uses. Med Plant Res 2013;3:70-7.

7. Tiwari P, Kumar B, Kaur M, Kaur G, Kaur H. Phytochemical screening and extraction. Int Pharm Sci 2011;1:98-106.

8. Saptarini NM, Deswati DA. The antipyretic activity of leaves extracts of Ceiba pentandra better than Gossypium arboreum. J Appl Pharm Sci 2015;5:118-21.

9. Saptarini NM, Deswita DA. Antipyretic activity of plantain (Plantago major L.) leaves extract in yeast-induced mice. Drug Invention Today 2019;12:1588-90.

10. https://www.cdc.gov/vaccines/hcp/vis/visstatements/dtap.html [Last accessed on 10 Aug 2020]

11. Dipiro J, Talbert R, Yee G, Matzke G, Wells B, Posey L. Pharmacotherapy: a pathophysiologic approach. New York: The McGraw-Hill Companies Inc; 2008. [Last accessed on 10 Aug 2020]

12. Parganiha R, Verma S, Chandrakar S, Pal S, Sawarkar HA, Kashyap P. In vitro anti-asthmatic activity of fruit extract of Piper nigrum (Piperaceae). Int J Herbal Drug Res 2011;1:15-8.

13. Bhaskar VH, Balakrishnan N. Analgesic, anti-inflammatory and antipyretic activities of Pergularia daemia and Carissa carandas. DARU 2009;17:168-17. 
14. Potduang B, Meeploy M, Giwanon R, Benmart Y, Kaewduang M, Supatanakul W, et al. Biological activities of Asparagus racemosus. Afr J Tradit Complement Altern Med 2008;5:230-7.

15. Pendota SC, Yakubu M, Grierson DS, Afolayan AJ. Antiinflammatory, analgesic and antipyretic activities of the aqueous extract of Hippobromus pauciflorus (Lf) radlk leaves in male wistar rats. Afr J Biotechnol 2009;8:2036-41.

16. Taiwe GS, Bum EN, Dimo T, Talla E, Sidiki NW, Dawe A, et al. Antipyretic and antinociceptive effects of Nauclea latifolia roots decoction and possible mechanisms of action. Pharm Biol 2011;49:15-25.

17. Adesokan AA, Yakubu MT, Owoyele BV, Akanji MA, Soladoye AO, Lawal O. Effect of administration of aqueous and ethanol extracts of Enantia chlorantha stem bark on brewer's yeast induced pyresis in rats. Afr J Biochem 2008;2:165-9.

18. Dillard GM, Bodel P. Studies on steroid fever. II. Pyrogenic and anti-pyrogenic activity in vitro of some endogenous steroids of man. J Clin Invest 1970;49:2418-26. 